\section{Ferric Chelate Reductase Activity in Roots of Two Annona Species as Affected by Iron Nutrition}

\author{
Maritza Ojeda ${ }^{1}$ \\ Horticultural Sciences Department, University of Florida, IFAS, P.O. Box \\ 110690, Gainesville, FL 32611
}

Bruce Schaffer ${ }^{2}$

Tropical Research and Education Center, University of Florida, IFAS, 18905

SW 280th Street, Homestead, FL 33031

Frederick S. Davies

Horticultural Sciences Department, University of Florida, IFAS, P.O. Box 110690, Gainesville, FL 32611

Additional index words. Annona glabra, pond apple, Annona muricata, soursop, chlorophyll, growth

Abstract. Root ferric chelate reductase (FCR) activity in Annona glabra L. (pond apple), native to subtropical wetland habitats and Annona muricata L. (soursop), native to nonwetland tropical habitats, was determined under Fe-sufficient and Fe-deficient conditions. Four-month-old seedlings of each species were grown hydroponically in a complete nutrient solution containing $90 \mu \mathrm{M} \mathrm{Fe}$ or no Fe. The degree of tolerance of Fe deficiency was evaluated by measuring root FCR activity, chlorophyll and Fe concentration in recently matured leaves and plant growth. Root FCR activity was higher in soursop than in pond apple in the nutrient solution with Fe. However, there were no differences in root FCR activity between species under Fe-deficient conditions. Root FCR activity in pond apple and soursop was not induced in the absence of Fe. Leaf chlorophyll index and Fe concentration, and dry weights of pond apple were lower when plants were grown without Fe compared to plants grown with Fe. Leaves of pond apple grown without Fe became chlorotic within 3 weeks. Lack of Fe decreased the chlorophyll index and Fe concentration in young leaves less in soursop than in pond apple. In contrast, the Fe level in the nutrient solution had no effect on dry weights of soursop. The rapid development of leaf chlorosis and low FCR activity of pond apple may be due to its native origin in wetland areas where there is sufficient soluble Fe for plant growth and development.

The Annonaceae includes several subtropical and tropical woody, perennial tree species with economic importance throughout the world. Two Annona species, Annona glabra L. (pond apple) and Annona muricata L. (soursop), show promise as flood-tolerant rootstocks for commercial Annona species (Núñez-Elisea et al., 1999) in areas that are prone to cyclical flooding, such as southern Florida. Annona glabra is native to subtropical areas in Florida, the Caribbean, and South America, and is often found growing in wetlands hence its common name, pond apple. Soursop is the most tropical Annona species, native to the Caribbean and South America (Nakasone and Paull, 1998; Popenoe, 1920). In some regions of the

Received for publication 17 Apr. 2003. Accepted for publication 11 July 2003. We thank Drs. Rebecca Darnell and Paul Lyrene for their helpful reviews and critical comments. We also thank Steven Hiss, Robert Davies, and Glenn Zalman for their technical assistance. Florida Agricultural Experiment Station Journal Series No. R-09038.

${ }^{1}$ Current address: Universidad Centroccidental Lisandro Alvarado, Apartado 400, Barquisimeto, Lara, Venezuela.

${ }^{2}$ To whom reprint requests should be addressed. E-mail address: bas@mail.ifas.ufl.edu world, tropical fruit trees, including Annona, are grown in calcareous soils. Calcareous soils have high $\mathrm{pH}$ (7.5 to 8.5), high concentration of bicarbonate, and generally a low organic matter content (Lucena, 2000). A common problem in these soils is an inadequate supply of soluble Fe, which results in Fe deficiency in many crops (Korcak, 1987; Tagliavini et al., 1995). Crops with Fe deficiency display leaf chlorosis and suppression of growth and yield (De la Guardia et al., 1995; Welkie, 1995; Zouari et al., 2001).

Plants need special mechanisms to obtain Fe from insoluble forms present in neutral and alkaline soils. Two different strategies evolved to alleviate Fe deficiency in plants: Strategy I and Strategy II (Marschner and Römheld, 1995). Strategy II plants are generally characterized by increases in biosynthesis and secretion of compounds that are highly effective as $\mathrm{Fe}^{3+}$ chelators (Marschner and Römheld, 1995). One of the most common physiological responses of Strategy I plants is increased activity of an inducible ferric chelate reductase (FCR) in root cell plasma FCR activity in response to $\mathrm{Fe}$ stress has been studied in many fruit crops, including peach membranes induced by Fe stress. Induction of
(De la Guardia et al., 1995), citrus (Castle and Manthey, 1998; Manthey et al., 1993, 1994; Pestana et al., 2001), avocado (Manthey and Crowley, 1997), and papaya (Marler et al., 2002). Some studies have indicated that root FCR activity in Fe-deficient plants was lower than that in Fe-sufficient plants (Gogorcena et al., 2000; Romera et al., 1991; Tagliavini et al., 1995; Zouari et al., 2001).

In nonflooded calcareous soils, Annona species require soil applications of chelated $\mathrm{Fe}$ to avoid Fe-deficiency. In these soils, pond apple requires more than three times the rate of chelated $\mathrm{Fe}$ than other Annona species to prevent the development of Fe-deficiency symptoms (B. Schaffer, unpublished data). Flooding calcareous soils results in a significant and rapid reduction of $\mathrm{Fe}^{3+}$ (Larson et al., 1991). Thus, FCR may be less inducible under Fedeficient conditions in pond apple than in other Annona species because in pond apple's native wetland habitat, $\mathrm{Fe}$ is readily available in the reduced form. The objective of this study was to compare the effects of $\mathrm{Fe}$ nutrition on root FCR activity in pond apple and soursop, two Annona species from different native habitats with potential for use as flood-tolerant commercial Annona rootstocks.

\section{Materials and Methods}

The study was conducted from July to November in a sunlit glasshouse in Gainesville, Fla. Average day/night air temperatures during the experimental period ranged from $32 / 25$ to $25 / 20{ }^{\circ} \mathrm{C}$, and relative humidity was $80 \%$ to $85 \%$. Air temperature and relative humidity were monitored with a Hobo H8 Pro Series (Onset Computer Corp., Pocasset, Mass.) temperature logger.

Pond apple and soursop seeds were sown in flats and 1-month-old seedlings were transplanted to 1-Lcontainers in a well-drained medium (40\% Florida peatmoss, $20 \%$ vermiculite, and $40 \%$ pine bark, by volume). Plants were fertigated monthly with $3.7 \mathrm{~g} \cdot \mathrm{L}^{-1}$ of watersoluble fertilizer (14.N-8P-16.6K; with ammonium, nitrate, and urea, as $\mathrm{N}$ sources). When seedlings were 4 months old, uniform trees of each species were selected, their root systems washed, and plants were transplanted to 2-L plastic bottles where they were grown hydroponically in a complete nutrient solution (described below). The plastic bottles were wrapped with aluminum foil to prevent algal growth. All plants were acclimated for 3 weeks in the complete nutrient solution, after which plants were transferred to the complete nutrient solution containing $90 \mu \mathrm{M} \mathrm{Fe}^{3+}$-DTPA [diethylenetriaminepenta-acetic acid, iron (III) disodium salt dihydrate] as the Fe source (plus $\mathrm{Fe}$ ), or a complete nutrient solution without $\mathrm{Fe}$ (minus $\mathrm{Fe}$ ). The nutrient solution also contained $5.0 \mathrm{~mm} \mathrm{NaNO}, 0.5 \mathrm{~mm} \mathrm{~K} \mathrm{HPO}_{4} \cdot 3 \mathrm{H}_{2} \mathrm{O}, 1.0$ $\mathrm{mm} \mathrm{MgSO}_{4} \cdot 7 \mathrm{H}_{2} \mathrm{O}, 0.5 \mathrm{~mm} \mathrm{CaCl} \cdot 2 \mathrm{H}_{2} \mathrm{O}, 0.045$ $\mathrm{mm} \mathrm{H}_{3} \mathrm{BO}_{3}, 0.01 \mathrm{~mm} \mathrm{MnSO} \cdot \mathrm{H}_{2} \mathrm{O}, 0.01 \mathrm{~mm}$ $\mathrm{ZnSO}_{4} \cdot 7 \mathrm{H}_{2} \mathrm{O}, 0.003 \mathrm{~mm} \mathrm{CuSO}_{4} \cdot 5 \mathrm{H}_{2} \mathrm{O}, 0.2 \mu \mathrm{M}$ $\mathrm{Na}_{2} \mathrm{MoO}_{4} \cdot 2 \mathrm{H}_{2} \mathrm{O}$. The solution $\mathrm{pH}$ was buffered with 10 mM MES [2-(4- morpholino)-ethane sulfonic acid] at $\mathrm{pH} 6.5$, and maintained at $\mathrm{pH}$ 6.5 by daily monitoring with a standard elec- 
trode attached to a pH meter (Accumet AP62; Fisher, Pittsburgh). The $\mathrm{pH}$ was adjusted as needed with $0.1 \mathrm{~N} \mathrm{KOH}$ or $0.1 \mathrm{~N} \mathrm{HCl}$. All solutions were aerated with individual aquarium air pumps (Elite 801; Rolf C. Hagen, Mansfield, Mass.) connected with tygon tubing located at the bottom of the 2-L plastic bottles. The airflow was adjusted to $1 \mathrm{~L} \cdot \mathrm{min}^{-1}$. Solutions were changed weekly and the study was conducted for 16 weeks.

Root FCR activity was monitored every 10 $\mathrm{d}$ from white root tips $\approx 1 \mathrm{~cm}$ long that were collected from each plant, placed in a beaker filled with ice water for $\approx 5 \mathrm{~min}$, and transferred to the laboratory. To reduce the amount of time between excision and root FCR activity measurements, plants were sampled and brought to the laboratory for determination of FCR activity in sets of six (three plants for each treatment). Root tips were weighed and $\approx 100$ $\mathrm{mg}$ tissue fresh weight was placed in a test tube. The root tips were rinsed for 5 min with $2 \mathrm{~mL}$ of $0.2 \mathrm{~mm} \mathrm{CaSO}_{4}$ and placed in $2 \mathrm{~mL}$ of the assay solution containing 5 mM MES buffer ( $\mathrm{pH}$ 5.5), $0.1 \mathrm{~mm} \mathrm{Fe}^{3+}$-EDTA, $10 \mathrm{~mm}$ $\mathrm{CaSO}_{4}$, and $0.3 \mathrm{~mm}$ sodium bathophenanthrolinedisulfonic acid (Na-BPDS). The samples were kept in the assay solution in the dark at $23{ }^{\circ} \mathrm{C}$ in a shaker water bath for $1 \mathrm{~h}(50$ $\mathrm{rpm})$. The amount of $\mathrm{Fe}^{2+}$ (BPDS) formed was measured colorimetrically at $535 \mathrm{~nm}$. Values were standardized using a blank assay solution without roots. The concentration of $\mathrm{Fe}^{2+}$-BPDS produced was calculated using the molar extinction coefficient of $22.14 \mathrm{~mm} / \mathrm{cm}$ (Welch et al., 1993), and root fresh weights to calculate Fe reduction activity.

Leaf chlorophyll index was determined with a chlorophyll meter (SPAD-502; Minolta Camera Co., Japan). Six of the most recently fully expanded leaves were used for leaf chlorophyll index determinations and expressed as SPAD readings.

Leaf $\mathrm{Fe}$ concentration was determined in the most recently fully expanded leaves at the end of the experiment. Six to seven leaves per plant in each treatment were sampled. Leaf samples were gently rinsed with running deionized water for $\approx 1 \mathrm{~min}$. Samples were ovendried at $70{ }^{\circ} \mathrm{C}$ for $48 \mathrm{~h}$. The dry samples were ground through a 40-mesh screen in a Wiley mill. The samples were prepared and processed for analysis using a dry ash procedure described by Hanlon et al. (1994). About $0.5 \mathrm{~g}$ of ground sample was transferred to a $10-\mathrm{mL}$ beaker and placed in a muffle furnace at $500{ }^{\circ} \mathrm{C}$ for 10 to1 $2 \mathrm{~h}$. After the sample was cooled, a few drops of $1 \mathrm{~N} \mathrm{HCl}$ were added to the ash, after which samples were rinsed with $1 \mathrm{~N} \mathrm{HCl}$ and transferred to a volumetric flask and brought to a volume of $50 \mathrm{~mL}$. The samples were mixed thoroughly, and then filtered through Whatman Q8 filter paper. Subsamples were transferred to $20 \mathrm{~mL}$ polyethylene scintillation vials for $\mathrm{Fe}$ analysis using an inductively coupled argon plasma spectrometer (Spectro-CIROS CCD; FTCEA000, Germany).

The fresh weights of whole plants were determined immediately prior to treatment initiation. At the end of the experiment, fresh and dry weights of leaves, stems (including axillary branches and shoots), and roots were determined with a Mettler BB240 electronic scale (Mettler, Greifensee, Switzerland). Prior to dry weight determinations, tissue samples were oven-dried to a constant weight at 70 ${ }^{\circ} \mathrm{C}$.

Treatments were randomly arranged as a 2 (species) $\times 2$ (Fe plus or minus) factorial experiment with $\mathrm{Fe}$ and species as the main effects. There were six single-plant replications for each treatment combination. Data were analyzed by analysis of variance, followed by LSMEANS test $(P<0.05)$ using SAS (SAS Inst., Cary, N.C.) statistical software. Leaf chlorophyll index and root and leaf FCR activity were analyzed as a split split-plot design.

\section{Results and Discussion}

There was a significant interaction between species and $\mathrm{Fe}$ concentration in the nutrient solution for almost all variables measured. Plant fresh weight (FW) of pond apple and soursop increased over the treatment period and both species continuously produced new roots throughout the study. However, pond apple (with a 158-g increase in plant FW) grew considerably more that soursop (with a $37-\mathrm{g}$ increase in plant FW). The relatively slow growth of soursop compared to pond apple may be attributed the temperatures in the glasshouse during the treatment period. Soursop is native to tropical climates and root temperatures lower than $25^{\circ} \mathrm{C}$ result in less plant growth compared to pond apple (Ojeda, 2003), which is indigenous to subtropical areas. There appeared to be no negative effect of the nutrient solution on soursop growth since plants in containers in the same glasshouse exhibited similar growth rates to those in the nutrient medium. The addition of $\mathrm{Fe}$ to the nutrient solution resulted in increased growth of pond apple by week 16, whereas soursop was not significantly affected by addition of Fe to the nutrient solution (data not shown). Pond apple grown without $\mathrm{Fe}$ exhibited visible $\mathrm{Fe}$ deficiency symptoms (interveinal chlorosis of leaves) within 3 weeks after treatments were initiated. Root, stem, and leaf dry weights of pond apple were lower for the minus Fe treatment than for the plus Fe treatment (Table 1). Reduced dry weights as a result of Fe deficiency have also been reported in other crops (Alcántara et al., 2000). For soursop, there was no significant effect of Fe treatment on plant dry weights.

Root FCR activity of pond apple in the minus Fe treatment decreased from $31 \mathrm{nmol}$ of $\mathrm{Fe}^{2+} / \mathrm{g} \cdot \mathrm{h}^{-1}$ on day 1 (prior to applying $\mathrm{Fe}$ treatments) to $\approx 17 \mathrm{nmol}$ of $\mathrm{Fe}^{2+} / \mathrm{g} \cdot \mathrm{h}^{-1}$ on the last treatment day and it was generally lower than root FCR activity in the plus Fe treatment throughout the study (Fig. 1). Soursop plants in the plus Fe treatment generally had higher root FCR activity than those in the minus Fe treatment. In the plus Fe treatment, the root FCR activity of soursop was significantly higher than that of pond apple in the plus $\mathrm{Fe}$ treatment, with the highest rate on day 40, with a transient increase on day 80 . If FCR in pond apple and soursop is inducible, FCR activity should presumably have been greater in the minus $\mathrm{Fe}$ than the plus Fe treatment as is typical in Strategy I plants (Marschner and Römheld, 1995). However, the opposite was observed for both pond apple and soursop. Therefore, the enhanced FCR activity in the plus Fe treatment may have been a result of healthier root systems and thus a greater expression of noninducible FCR. Some studies have shown that root FCR activity is more likely to be induced at very low Fe concentrations than by the absence of Fe (Zouari, 2001). Thus, it is possible that under Fe-deficient conditions, pond apple and soursop still require low levels of Fe for FCR induction.

Soursop in the minus Fe treatment exhibited a decrease in root FCR activity within $10 \mathrm{~d}$ after treatments were initiated. In this respect, soursop and pond apple differ from many herbaceous plants (Romera et al., 1992; Römheld and Marschner, 1983; Zaharieva and Römheld, 2000) and other fruit crops (Castle and Manthey, 1998; Manthey et al., 1994; Marler et al., 2002; Pestana et al., 2001; Romera et al., 1991), which show an increase in root FCR activity under Fe deficient conditions. Under our conditions, root FCR activity decreased when plants were grown without Fe, indicating they were unable to respond to lack of Fe by increasing their Fe-reducing capacity. There is a considerable variability in root FCR activity among woody plant species in response to $\mathrm{Fe}$ deficiency. For Ficus growing with no $\mathrm{Fe}$ in the medium, root FCR activity was $5000 \mathrm{nmol}$ $\mathrm{Fe}^{2+} / \mathrm{g} \cdot \mathrm{h}^{-1}$ (Rosenfield et al., 1991). For some peach clones grown without Fe, FCR activity was between 2500 and $6000 \mathrm{nmol} \mathrm{Fe} \mathrm{Fe}^{2+} / \mathrm{g} \cdot \mathrm{h}^{-1}$ (De la Guardia et al., 1995). In contrast, root FCR activity of pear growing without Fe was $29 \mathrm{nmol} \mathrm{Fe} \mathrm{e}^{2+} / \mathrm{g} \cdot \mathrm{h}^{-1}$ (Tagliavini et al., 1995) and quince growing without Fe was only $3 \mathrm{nmol}$ $\mathrm{Fe}^{2+} / \mathrm{g} \cdot \mathrm{h}^{-1}$ (Tagliavini et al., 1995). Thus, the low FCR activity observed for pond apple and soursop were similar to low activities observed for some other woody fruit crop species.

Leaf chlorophyll index was similar in both species with and without $\mathrm{Fe}$ until the third week after treatments were initiated (Fig. 2). Leaf chlorophyll index of both pond

Table 1. Effect of Fe on dry weights of pond apple and soursop 16 weeks after treatments were initiated.

\begin{tabular}{lcccr}
\hline & \multicolumn{4}{c}{ Dry wt $(\mathrm{g})$} \\
\cline { 2 - 5 } Species & Treatments & Root & Stem & Leaves \\
\hline Pond apple & $(-) \mathrm{Fe}$ & $14.90 \mathrm{~b}^{\mathrm{z}}$ & $16.06 \mathrm{~b}$ & $3.67 \mathrm{~b}$ \\
& $(+) \mathrm{Fe}$ & $24.10 \mathrm{a}$ & $24.94 \mathrm{a}$ & $12.23 \mathrm{a}$ \\
Soursop & $(-) \mathrm{Fe}$ & $4.67 \mathrm{a}$ & $3.63 \mathrm{a}$ & $2.41 \mathrm{a}$ \\
& $(+) \mathrm{Fe}$ & $3.48 \mathrm{a}$ & $3.69 \mathrm{a}$ & $2.57 \mathrm{a}$ \\
\hline
\end{tabular}

${ }^{\mathrm{z}}$ Means followed by different letters indicate significant differences between Fe treatments $(P \leq 0.01)$ within each species, $\mathrm{n}=$ six plants. 
apple and soursop leaves was significantly reduced by Fe stress. However, the apical leaves of pond apple grown without Fe developed earlier and more severe chlorosis symptoms than soursop leaves grown without Fe. The severity of visual symptoms of pond apple to Fe deficiency consistently increased until the end of the experiment, when the leaves were completely yellow (low leaf chlorophyll index). A highly significant linear relationship between extractable leaf chlorophyll and leaf chlorophyll index (SPAD readings) has been reported in Annona species (Schaper and Chacko, 1991). No significant differences in leaf chlorophyll index were detected between pond apple and soursop grown with $\mathrm{Fe}$.

At the end of experiment, leaf Fe concentration in both soursop and pond apple was significantly lower in plants grown without $\mathrm{Fe}$ than in plants grown with Fe (Fig. 3). Values of leaf $\mathrm{Fe}$ concentration between 40 and 70 $\mathrm{mg} \cdot \mathrm{kg}^{-1}$ have been reported to be in the sufficiency range for other Annona species such as atemoya (Annona squamosa L. X Annona cherimola Mill.) (Sanewski, 1991). The differences in the intensity of responses between the two Annona species may partially explain the differences in tolerance to Fe-deficient soils. There was a greater difference in chlorophyll index between the plus and minus Fe treatments for pond apple than soursop indicating a greater susceptibility of pond apple to Fedeficiency. The limited growth of soursop in both Fe treatments, as a possible result of low temperatures, may explain why soursop did not exhibit severe chlorosis, even in the minus $\mathrm{Fe}$ treatment. Thus, there may have been less of a dilution effect on leaf Fe content for soursop than for pond apple.

Based on the results of this study, both pond apple and soursop appear to be susceptible to Fe-deficiency and FCR is not induced in the complete absence of $\mathrm{Fe}$ in the medium. However, further studies are needed to determine if under Fe-deficient conditions, some $\mathrm{Fe}$ is required for FCR induction. Pond apple is more susceptible to Fe deficiency than soursop, as indicated by very low leaf chlorophyll content and more pronounced $\mathrm{Fe}$-deficiency symptom expression in the minus Fe treatment. The rapid development of leaf chlorosis and low FCR activity of pond apple may be due to its native origin in wetland areas where there is sufficient soluble Fe in the soil for plant growth and development.

\section{Literature Cited}

Alcántara, E., F.J. Romera, M. Cañete, and M.D. de la Guardia. 2000. Effects of bicarbonate and iron supply on Fe(III) reducing capacity of roots and leaf chlorosis of the susceptible peach rootstock 'Nemaguard'. J. Plant Nutr. 23:1607-1617.

Castle, W.S. and J.A, Manthey. 1998. Screening citrus rootstocks for iron-deficiency tolerance. Fruits 53:375-381.

De la Guardia, M.D., A. Felipe, E. Alcántara, J.M. Fournier, and F.J. Romera. 1995. Evaluation of experimental peach rootstocks grown in nutrient solutions for tolerance to iron stress. p. 201-205. In: J. Abadia (ed.). Iron nutrition in soils and plants. Kluwer Acad. Publ., Netherlands.

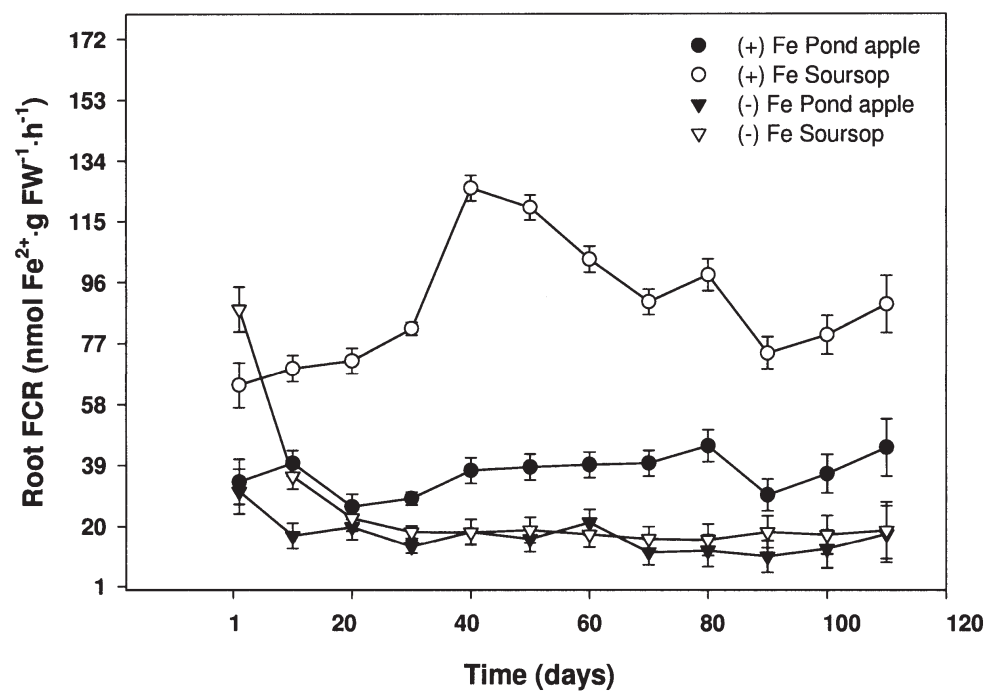

Fig. 1. Effect of Fe concentration in the nutrient solution on root FCR activity of pond apple and soursop plants. Data points represent means \pm SE.

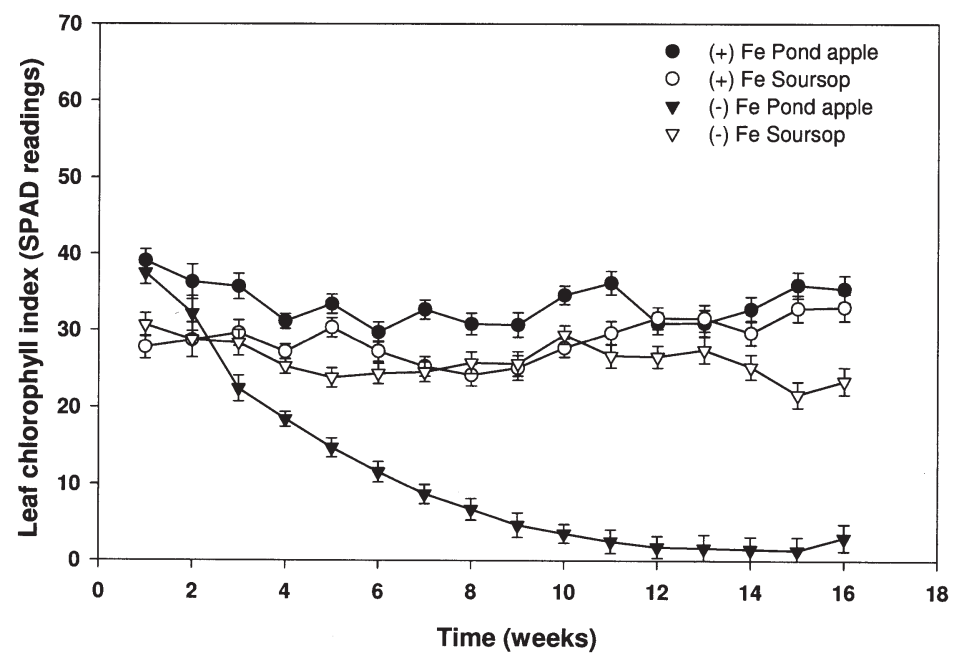

Fig. 2. Effect of Fe on leaf chlorophyll index (SPAD readings) of pond apple and soursop plants. Data points represent means $\pm \mathrm{SE}$.

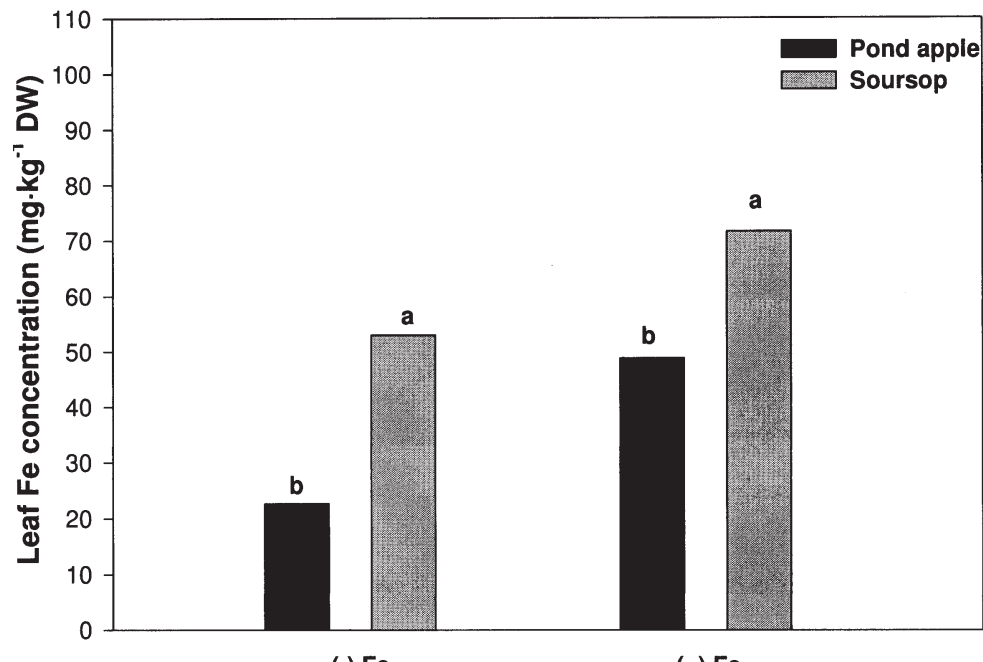

$(-) \mathrm{Fe}$

(+) $\mathrm{Fe}$

Fe treatment

Fig. 3. Effect of Fe-treatment on leaf Fe concentration of pond apple and soursop plants 16 weeks after treatments were initiated. Means with different letters indicate significant difference between species in each Fe treatment by LSMEANS $(P \leq 0.01)$. 
Gogorcena, Y., J. Abadía, and A. Abadía. 2000. Induction of in vivo root ferric chelate reductase activity in fruit tree rootstock. J. Plant Nutr. 23:9-21.

Hanlon, E.A., J.G. González, and J.M. Bartos. 1994. IFAS Extension soil testing laboratory chemical procedures and training manual. Fla. Coop. Ext. Serv., IFAS, Univ. of Florida, Gainesville. Circ. 812.

Jolley, V.D., K.A. Cook, N.C. Hansen, and W.B. Stevens. 1996. Plant physiological responses for genotypic evaluation of iron efficiency in Strategy I and Strategy II plants - A review. J. Plant Nutr. 19:1241-1255.

Korcak, R.F. 1987. Iron deficiency chlorosis, $\mathrm{p}$ 133-186. In: J. Janick (ed.). Hort. Rev. Vol. 9. Wiley, New York.

Larson, K.D., D. Graetz, and B. Schaffer. 1991. Flood-induced chemical transformations in calcareous agricultural soils of south Florida. Soil Sci. 152:33-40.

Lucena, J.J. 2000. Effect of bicarbonate, nitrate and other environmental factors on iron deficiency chlorosis. A review. J. Plant Nutr. 23: 1591-1606.

Manthey, J.A. and D.E. Crowley. 1997. Leaf and root responses to iron deficiency in avocado. $\mathrm{J}$. Plant Nutr. 20:683-693.

Manthey, J.A., D.L. McCoy, and D.E. Crowley. 1993. Chelation effects on the iron reduction and uptake by low-iron stress tolerant and non-tolerant citrus rootstocks. J. Plant Nutr. 16:881-893.

Manthey, J.A., D.L. McCoy, and D.E. Crowley. 1994. Stimulation of rhizosphere iron reduction and uptake in response to iron deficiency in citrus rootstocks. Plant Physiol. Biochem. 32:211-215.

Marler, T.E., R. De la Cruz, and A.L. Blas. 2002 Iron deficiency induced changes in iron reductase activity in papaya roots. J. Amer. Soc. Hort. Sci. 127:184-187.

Marschner, H. and V. Römheld. 1995. Strategies of plants for acquisition of iron, p. 375-388. In: J. Abadia (ed.). Iron nutrition in soils and plants. Kluwer Acad. Publ., Netherlands.

May, G.M., M.P. Pritts, and M.J. Kelly. 1994. Seasonal patterns of growth and tissue nutrient content in strawberries. J. Plant Nutr. 17: 1149-1162.

Nakasone, H.Y. and R.E. Paull. 1998. Tropical fruits. CAB Intl., Wallingford, U.K.

Núñez-Elisea, R., B. Schaffer, J.B. Fisher, A.M. Colls, and J.H. Crane. 1999. Influence of flooding on net $\mathrm{CO}_{2}$ assimilation, growth, and stem anatomy of Annona species. Ann. Bot. 84: 771-780.

Ojeda, M.G. 2003. Flooding, soil temperature, iron nutrition, physiology, and growth of Annona species. PhD Diss., Univ. of Florida, Gainesville.

Pestana, M., M. David, A. de Varennes, J. Abadía, and E. Aráujo. 2001. Response of 'Newhall' orange trees to iron deficiency in hydroponics: effects on leaf chlorophyll, photosynthetic efficiency, and root ferric chelate reductase activity. J. Plant Nutr. 24:1609-1620.

Popenoe, W. 1920. Manual of tropical and subtropical fruits. Hafner Press, Macmillan Publishers, London.

Romera, F.J., E. Alcántara, and M.D. de la Guardia. 1991. Characterization of the tolerance to iron chlorosis in different peach rootstock grown in nutrient solution. II. Iron-stress response mechanisms. Plant and Soil 130:121-125.

Romera, F.J., E. Alcántara, and M.D. de la Guardia. 1992. Effects of bicarbonate, phosphate and high $\mathrm{pH}$ on reducing capacity of $\mathrm{Fe}$-deficient sunflower and cucumber plants. J. Plant Nutr. 15:1519-1530.
Römheld, V. and H. Marschner. 1983. Mechanism of iron uptake by peanut plants. Plant Physiol. 71:949-954

Rosenfield, C.L., D.W. Reed and M.W. Kent. 1991. Dependency of iron reduction on development of a unique root morphology in Ficus benjamina L. Plant Physiol. 95:1120-1124.

Schaper, H. and E.K. Chacko. 1991. Relation between extractable chlorophyll and portable chlorophyll meter readings in leaves of eight tropical and subtropical fruit-tree species. Plant Physiol. 138:674-677.

Sanewski, G.M. 1991. Custard apples-Cultivation and crop protection. Inform. Ser. QI90031, Queensland Dept. of Primary Industries, Brisbane, Australia.

Tagliavini, M., A.D. Rombolá, and B. Marangoni. 1995. Response to iron-deficiency stress of pear and quince genotypes. J. Plant Nutr. 18: 2465-2482.

Welch, R.M., W.A. Norvell, S.C. Schaefer, J.E. Shaff, and L.V. Kochian. 1993. Induction of iron (III) reduction in pea (Pisum sativum L.) roots by $\mathrm{Fe}$ and $\mathrm{Cu}$ status: Does the root-cell plasmalemma Fe(III)-chelate reductase perform a general role in regulating cation uptake? Planta 190:555-561.

Welkie, G.W. 1995. Effects of root temperature on iron stress responses, p. 229-234. In: J. Abadia (ed.). Iron nutrition in soils and plants. Kluwer Acad. Publ., Netherlands.

Zaharieva, T. and V. Römheld. 2000. Specific $\mathrm{Fe}^{2+}$ uptake system in Strategy I plants inducible under Fe deficiency. J. Plant Nutr. 23: 1733-1744.

Zouari, M., A. Abadía, and J. Abadía. 2001. Iron is required for the induction of ferric chelate reductase activity in iron-deficient tomato. J. Plant Nutr. 24:383-396. 